\begin{tabular}{|l|l|}
\hline Vitoria y los intereses de la conquista de América & Titulo \\
\hline Miranda, José - Autor/a; & Autor(es) \\
\hline México & Lugar \\
\hline El Colegio de México & Editorial/Editor \\
\hline 1947 & Fecha \\
\hline Jornadas no. 57 & Colección \\
\hline Conquista; Historia; Vitoria, Francisco de; & Temas \\
\hline Libro & Tipo de documento \\
\hline "http://biblioteca.clacso.org/Mexico/ces-colmex/20200911025320/jornadas-57.pdf" & URL \\
\hline $\begin{array}{l}\text { Reconocimiento-No Comercial-Sin Derivadas CC BY-NC-ND } \\
\text { http://creativecommons.org/licenses/by-nc-nd/2.0/deed.es }\end{array}$ & Licencia \\
\hline
\end{tabular}

Segui buscando en la Red de Bibliotecas Virtuales de CLACSO http://biblioteca.clacso.org

Consejo Latinoamericano de Ciencias Sociales (CLACSO)

Conselho Latino-americano de Ciências Sociais (CLACSO)

Latin American Council of Social Sciences (CLACSO)

www.clacso.org

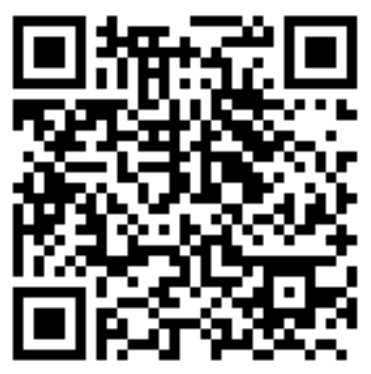




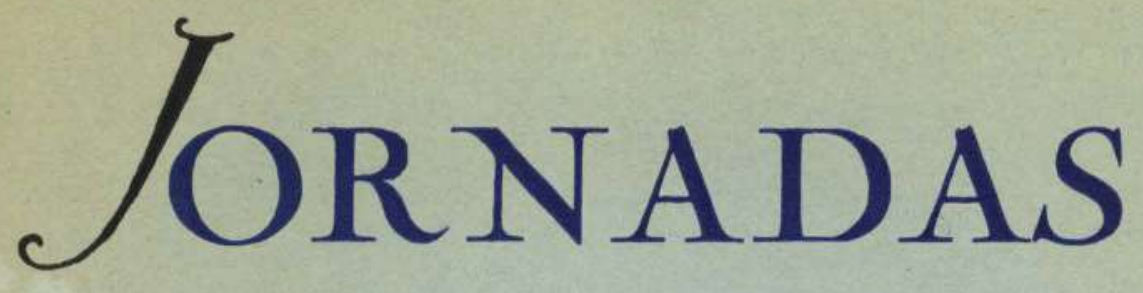

57

JOSE/MIRANDA $1903-1967$

\section{VITORIA Y LOS INTERESES DE LA CONQUISTA DE AMERICA}

\section{8 \\ J88 \\ no. 57 \\ ej, 3}

EL COLEGIO DE MEXICO 


\section{EL COLEGIO DE MEXICO SEVILLA, 30 MEXICO, D. F.}

JUNTA DE GOBIERNO:

Alfonso Reyes, Presidente; Daniel Cosío Villegas, Secretario-Tesorero; Daniel F. Rubín de la Borbolla, Secretario Ejecutivo; Gustavo Baz, Alfonso Caso, Gonzalo Robles, Eduardo Villaseñor.

CENTRO DE ESTUDIOS HISTORICOS

CENTRO DE ESTUDIOS LITERARIOS

SEMINARIO SOBRE EL PENSAMIENTO HISPANO-AMERICANO

\section{JOR NADAS}

Toda correspondencia debe enviarse a Sevilla, 30 - México, D. F. 
308/J88/no.57/ej.3 306412

Miranda,

Vitoria $y$...

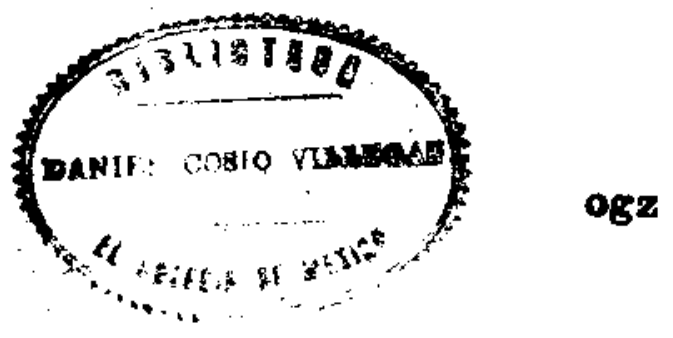

EL COLEGIO DE MEXICO

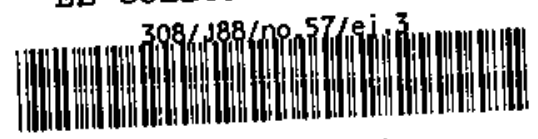

\#3 $9050014005 \mathrm{H}^{*}$ 

JOSE MIRANDA, $1903-1967$

Vitoria y los intereses de la
conquista de América

Open access edition funded by the National Endowment for the Humanities/Andrew W. Mellon Foundation Humanities Open Book Program.

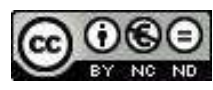

The text of this book is licensed under a Creative Commons Attribution-NonCommercial-NoDerivatives 4.0 International License: https://creativecommons.org/licences/by-ncnd/4.0/

JORNADAS -57

El Colegio de México

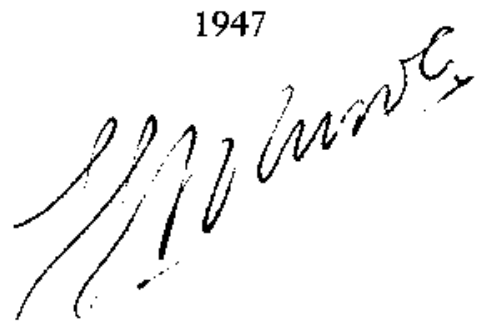


303412

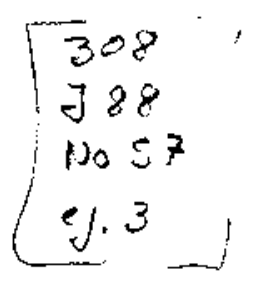




\section{PREAMBULO}

\section{1) NECESIDAD DE ESTUDIOS IMPARCIALES Y CRITICOS DE LA OBRA DE VITORIA}

Con propósitos ajenos a la ciencia, la obra de Vitoria ha sido desorbitada. Unas veces, para desvanecer la leyenda negra de la dominación española en América; ${ }^{1}$ otras, para desmentir la decadencia de la escolástica durante el siglo xvi; ${ }^{2}$ otras, en fin, para realzar las excelencias de la llamada época imperial hispana.

A fin de que puedan apreciarse mejor los desorbitamientos señalados, of recemos a continuación varios botones de muestra.

"Frecuentemente se ha considerado a Vitoria -escribe el P. Beltrán- como hombre doctrinario, cuyo pensamiento se desenvuelve en las regiones de la especulación y de los principios, sin que llegase a in-

1 Atribuyen algunos a las ideas vitorianas un influjo decisivo sobre el pensamiento y la legislación españoles del xu acerca de América. Para ellos, Vitoria sería el guía teórico de uno de los movimientos humanitarios más excelsos de la historia.

2 La decadencia de la escolástica se inicia poco después de Santo Tomás y es ya ostensible en el siglo xv. El florecimiento de la escolásrica en España durante el siglo xvI es un florecimiento local y superficial, un ligero y corto reverdecer en nuevos campos -en aquellos que el descubrimiento de Ámérica y la reorganización de la Iglesia abrieron a la consideración de los teólogos españoles-. Estos operaron en dichos campos más como españoles que como teólogos. Porque se trataba más de problemas políticonacionales que de problemas especulativo-filosóficos; de justificar teóricamente lo que era conveniencia e interés nacional, que de fundar mejor y extender más los puros principios teológicos. Los nuevos desarrollos de la teología en España tienden más que nada a justificar o legitimar realidades. Las readaptaciones forzosas de los viejos conceptos tendrán como objeto amoldarlos a las exigencias de esas justificaciones o legitimaciones teóricas. 
fluir directamente en la marcha de las cosas. Yo c re o que más que a nadie, más aún que al propio las Casas, deben los pueblos hispanoamericanos su salvación al insigne $j$ urista. Si en un principio las luchas entabladas por los delegados de los primeros apóstoles del Nuevo Mundo ante el Consejo de Indias impulsaron a Vitoria a dilucidar con tanto empeño este asunto, los razonamientos de esos misioneros solían ir virtualmente respaldados por el dictamen de Vitoria o sus discípulos. Eso daba consistencia y autoridad a sus reclamaciones, que después se traducían en leyes humanitarias y de protección, de que hoy podemos justamente enorgullecernos como pueblo colonizador... Y las armas de que se sirven aquellos defensores de la libertad son siempre las mismas: los dictados áureos del inmortal autor de las relecciones De Indis. Sin ruido, desde su aula, en menos de un cuarto de siglo, Vitoria había conquistado totalmente el campo." 8

"Nos hemos extendido tanto comentando la materia De Indis -advierte el P. Getino-, porque en ella se desenvolvió el espíritu de Vitoria, preparando las leyes que son nuestro timbre de gloria." "Idealismos [los de Vitoria y las Casas] -afinma más adelante- imposibles de aceptar por guerreros, pero idealismos salvadores que se impusieron, ya que no en la conquista, por lo menos en la magnánima legislación de Indias, monumento el más humano y venerable de cuantos se registran en la legislaciónde los pueblos dominadores."

"Fuera de San Agustín y Santo Tomás, con algunas otras figuras de la antigüedad -clama el P. Carro, hablando de Vitoria-, que se levante el teólogo que tenga en su haber otro tanto dentro de la verdadera ciencia, que es la expresión de la ciencia divina. A su lado pueden reclamar un puesto de honor el Cardenal Torquemada y Melchor Cano... La mayoría y la casi totalidad de los restantes teólogos que registra la listoria pueden ser teólogos eminentes y gozar de renombre

3 Vicente Beltrán de Heredia, "Ideas del Maestro Fray Francisco de Vitoria anteriores a las relección $D e$ Indis acerca de la colonización de América, según documentos inéditos", Anuario de la Asociación Francisco de Vitoria, II, p. 51.

4 Luis G. Alonso Getino, El Maestro Francisco de Vitoria, Madrid, 1930, p. 154.

5 Ibid., p. 172. 
indiscutible y merecido; pero no estuvieron dotados de ese quid divino propio del genio creador." ${ }^{6}$

"Se ha visto, según nuestro leal entender -perora el Pbro. Marcos-, cómo Carlos V y el Maestro Vitoria no sólo no fueron enemigos, sino que fueron buenos amigos, en orden a nuestra primera soberanía en América. Y es que ambos coincidían en el mismo ideal de nuestra actuación soberana, el de realizar las dos empresas universales más altas y fecundas de la razón y la fe; la perfección natural de todo bombre por el bumanismo y su perfección sobrenatural mediante el catolicismo. Humanizar a todos los hombres, deificar en lo posible a todos los hombres; esa era la empresa de España en América...; era el impulso perenne de la mente y el corazón, de las normas y de los mandatos, de la pluma y la espada del Maestro y del César." 7

No necesitamos decir que hacen un flaco servicio a Vitoria los escritores que, con los referidos propósitos, desencajan y fuerzan su pensamiento. El carácter panegírico y tendencioso de la mayor parte de la literatura sobre Vitoria más bien previene o predispone contra el eximio alavés. Sin contar, además, el daño que se le infiere al desplazarlo con divisa beligerante hacia campos donde se libran todavía hoy, por desgracia, enconadas contiendas ideológicas. ${ }^{8}$

Y no es que las obras en que aquellos propósitos imperan dejen de tener valor. Algunas lo tienen incluso muy subido - si se prescinde, claro está, de las consideraciones y juicios provocados por el espíritu de parcialidad, o también, a veces, por el excesivo encariñamiento con la figura del preclaro pensador.

- Venancio Carro, La teología y los teólogos-juristas españoles en la Conquista de América, Madrid, 1944, 1, pp. 416-417.

7 Teodoro Andrés Marcos, Vitoria y Carlos $V$ en la soberanía de Hispano-América, $2^{a}$ ed., Salamanca, 1946, p. 224.

8 Estas contiendas no sólo se libran aún, al enjuiciar la dominación española en América, entre católicos y no católicos, nacionalistas españoles y nacionalistas anglosajones, hispanófilos e hispanófobos, sino también, como antaño, entre eclesiásticos y civiles, dominicos y franciscanos, etc. Véase la obra del Padre Carro citada antes (nota 6), donde se mantienen tesis católicas, hispanófilas, clericales y dominicas. Obsérvese la saña con que combate el autor al insigne americanista Serrano Sanz, ardiente defensor del poder temporal, el menosprecio con que trata a Scoto y la baja estimación que da a la labor de los franciscanos en América. 
De todas maneras, debido a lo susodicho, siempre habrá que utilizar con precaución la literatura relativa a Vitoria. La mezcla que en casi toda ella hay de erudición de buena cepa y de desahogo tendencioso obligará a extremar la cautela a quienes la consulten o empleen. Por otra parte, una literatura significada en general por su tinte apologético no puede menos de ofrecer una importante laguna: la correspondiente a la parte crítica, que brilla por su ausencia allí donde juicios y observaciones carecen de ecuanimidad.

Así pues, nada de particular tiene que se sienta palpablemente la necesidad de estudios imparciales o desapasionados de la obra vitoriana, y también de estudios críticos propiamente dichos, es decir, que se propongan calibrar con las medidas más objetivas posibles el valor e importancia de esa obra.

¿Cuándo veremos al Vitoria sublimado y mítico -que conviene a la política- batirse en retirada ante el Vitoria de "carne y hueso" -que conviene a la ciencia?

2) ESPECIAL NECESIDAD DE ESTUDIOS SOBRE LA RELACION DE LAS IDEAS DE VITORIA CON LOS INTERESES DE LA CONQUISTA DE AMERICA

Las ideas del P. Vitoria sobre la conquista de América han merecido ya la atención de numerosos eruditos (teólogos, filósofos, juristas e historiadores), atraídos sin duda por lo que en ellas hay de original, profundo o generoso. Se las ha enfocado desde distintos ángulos, perseguido corriente arriba y abajo, sometido a disecciones totales o parciales y revelado en diferentes nexos.' Sin embargo, hasta hoy, que sepamos, ninguna pesquisa se ha hecho para determinar su relación con los intereses de dicha conquista. Tal omisión, empero, es común al estudio de todas las ideas sobre ese suceso histórico: nadie las ha examinado como factores determinantes del mismo que concurren en él con los intereses,

9 Una lista bastante amplia de las publicaciones en torno a Vitoria y su obra puede hallarse en Antonio Truyol Serra, Los principios del Derecho público en Francisco de Vitoria, Madrid, 1946. 
otros de sus factores determinantes; nadie ha asociado ideas e intereses, ni analizado nadie la interrelación e interacción de unas y otros en el proceso general de la Conquista; ello no obstante que la comprensión y explicación de este proceso reclamen o aconsejen tales intentos. ${ }^{10}$

10 La falta de estudios sobre las relaciones existentes entre las ideas y los intereses de la Conquista se debe, en gran parte, a que los intereses, tanto en su conjunto como en sus grupos o sectores y unidades, no han sido aún determinados y analizados sistemáticamente. Sólo conocemos un breve estudio parcial de los intereses particulares: Silvio Zavala, Los intereses particulares de la Conquista de la Nueva España, Madrid, 1933. 



\section{I \\ LAS IDEAS Y LOS INTERESES DE LA CONQUISTA}

Las ideas de la Conquista pueden o no haber surgido al calor de intereses institucionales o de grupo, mas resulta evidente que las instituciones y los grupos se valieron de ellas para favorecer o apoyar sus intereses.

Difícil es separar en cada pensador contemporáneo que intervino en la discusión ideológica de la Conquista la parte de sus doctrinas que está instigada por intereses, de la parte que lo está por convicciones o sentimientos desvinculados. Puede que esta parte tenga una extensión menos reducida de lo que a primera vista parece. Pero, sea cualquiera su dimensión y alcance, consideramos obvio que las ideas de este sector fueron también utilizadas en defensa o justificación de intereses institucionales o de grupo, relegándose a lugar secundario su finalidad primordial. Era inevitable que, en pro de sus intereses, las instituciones y los grupos emplearan como arsenal teórico, según sus conveniencias, el que por uno u otro conducto (el de la parcialidad o el de la imparcialidad) les deparó la época. Por ello, en definitiva, las ideas y los principios acabaron por abandonar casi completamente su marco propio, el teológico y moral, para instalarse dentro del ideológico, donde su condición quedó reducida, en primer término, a la de armas de combate en luchas de intereses.

La Conquista suscitó varios y distintos intereses, opuestos unos, coincidentes otros.

A los efectos de este breve estudio, basta consignar sucintamente aquí los principales intereses de instituciones y grupos, que fueron:

\section{A] Los de la Corona.}

En el orden interno -que es al que vamos a limitarnos-11 cabe reputar como principales intereses de esta institución:

${ }^{11}$ En el orden extemo los intereses son otros, y tienen su raiz en las luchas y 
a) impedir que arraigase en América el feudalismo,

b) constituir a los indios en vasallos directos del rey y

c) mantener en posición subordinada al poder espiritual.

Reduciéndolos a uno solo: implantar el absolutismo en Ultramar en iguales condiciones y términos que en España.

B] Los de la Iglesia.

En el orden interno también, cabe considerar como intereses primordiales de esta institución:

a) constituir a los indios en fieles y miembros directos de la comunidad religiosa,

b) evitar que personas extrañas se inmiscuyesen en la administración eclesiástica y

c) supeditar los fines temporales a los espirituales.

Reduciéndolos a uno solo: regir la vida espiritual de todos sin exclusión de nadie ni intromisiones ajenas.

C] Los de los conquistadores-encomenderos.

Cabe conceptuar como intereses capitales de este grupo los consistentes en conservar y aumentar los privilegios obtenidos, es decir, la posición aristocrática con relación a los demás españoles y la feudal -de intermediario en lo político y eclesiástico- con relación a los indios.

Por ley biológico-social, las instituciones y los grupos se plegaron a sus interesas y adoptaron las ideas que mejor se amoldaban a ellos o que más los favorecían. En general, las instituciones y grupos susodichos terminaron por aceptar como justo título de conquista la propagación de la fe y como causa justa de guerra la oposición a las actividades que la evangelización entrañaba; pero discreparon fundamentalmente en lo relativo a la naturaleza de los indios.

Fué sobre este particular donde el antagonismo radical de intereses impidió la coincidencia de ideas, posible en otros puntos.

pugnas entre estados, dinastías, iglesias, etc. Por lo que se refiere a la Monarquía y a la Iglesia españolas, sus intereses exteriores influyeron decisivamente sobre sus intereses internos. La política del aumento de poder hacia fuera tenía que traer como consecuencia la política de vigorización interna -la unificación, el intervencionismo, la centralización, etc. 
Los conquistadores-encomenderos podían transigir con que la propagación de la fe constituyese fundamento teórico de la Conquista, puesto que ello no suponía, necesariamente, consecuencias prácticas perjudiciales a sus intereses; pero no podían allanarse al principio de la igualdad natural de españoles e indios, ya que esto tenía que acarrearles nocivos efectos prácticos - principalmente, su cese como intermediarios entre los indios y el poder religioso y civil, con pérdida de importantes privilegios y merma de influjo social. Por el contrario, la Corona y la Iglesia no podían admitir teóricamente la inferioridad natural del indio propugnada por los encomenderos porque ello supondría la renuncia, en la práctica, a los beneficios implícitos en el sometimiento directo del indio como vasallo y como fiel.

Lo que se sostuvo, pues, en teoría por grupos e instituciones se acomodaba a lo que sus intereses pedían en la práctica. No puede ignorarse, sin embargo, que el respeto de los sentimientos humanos y religiosos dominantes a la sazón $-y$ en los que enraizaban no poco las ideas- constituyeron freno o traba de todos los intereses. Pero los que, por razón de ideas, rendían parias en principio a dichos sentimientos, supieron arreglárselas para que en la práctica la precipitación o condensación de éstos no causase a sus intereses mayores inconvenientes. Procedieron como casi siempre han procedido los gobernantes, caudillos o líderes: pusieron por encima de todo declaraciones de principios, derechos humanos, normas fundamentales, etc., que no aniquilaban sus intereses, aunque entrañasen limitaciones a los mismos, y luego, en la práctica, procuraron reducir al mínimo los efectos restrictivos, adversos a sus intereses, de esos principios, derechos o normas. Por ello, a pesar de que la Iglesia y la Corona sustenten sobre la naturaleza de los indios ideas más humanitarias que los conquistadores-encomenderos, no rebasan casi a éstos en cuanto al tratamiento que en la práctica debía darse al indígena; coincidirían con ellos en lo esencial: en que el mejor régimen aplicable a los naturales era el de tutela o protección. Fué, sin remedio, en la práctica, donde hubo de sentirse implacablemente la amortiguación del efecto restrictivo de los principios y donde había de patentizarse diáfanamente que las "nobles" ideas fueron esgrimidas por las instituciones con el fin principal de combatir intereses contrarios a los suyos y no con el de elevar correspondientemente en la realidad la condición 
del indio. ${ }^{12}$ Concretamente, se trataba de reemplazar a los encomenderos en la tutela directa de los indios y no de mejorar la situación efectiva de éstos. ${ }^{13}$ Claro es que del "pecado" de poner las ideas al servicio de los intereses cabe acusar a las instituciones y los grupos, mas no a muchos de los ideólogos que se consagraron a sostener doctrinas filantrópicas. Suum cuique, sin embargo; pues en la raíz de los intereses había también entrega a nobles empresas humanas (descubrir y explorar el mundo, civilizar naciones, fundar pueblos, etc.) ${ }^{14}$ empresas que no hu-

12 Podrían mostrarse numerosos ejemplos en comprobación de lo que aseveramos. Baste, sin embargo, con uno de los más demostrativos: A mediados del siglo xvi la Audiencia de México, quizá incitada por el espíritu humanitario de que hacían gala la legislación real y la mayoría de los escritos de la época, decidió proponer al filantrópico monarca una medida que le pareció aparejada para mejorar de manera efectiva la condición material del indígena, y que fué la de que se redujeran a la mitad los tributos que los indios pagaban a los encomenderos o a la Corona, con el objeto de aplicar a las cajas de comunidad indígenas lo correspondiente a la parte liberada de tributos. Pues bien, la Corona, tan dispuesta siempre a emitir declaraciones cuajadas de humanitarismo teórico, rechazó airadamente la propuesta de humanitarismo práctico por provisión de 3 de octubre de 1559, que inserta Puga en su Cedulario, t. II, p. 336, edición mexicana: "Si ansi pasare -contesta el monarca- sería quitarnos lo más de nuestras rentas..."; "no os entrometáis a quitar tributos de los indios".

13 A consecuencia de la victoria de la Corona y la Iglesia sobre los encomenderos, los indios cambiaron de tutores o protectores: pasaron de la dependencia de los encomenderos a la de los funcionarios reales (los corregidores y alcaldes mayores, principalmente); $y$ hay inmenso caudal de pruebas para abonar la conclusión de que estos funcionarios no esquilmaron y vejaron a los indios menos que los encomenderos. Tal cosa no impide, sin embargo, el que sólo los encomenderos sean considerados como representantes por excelencia de la opresión colonial. La palabra encomendero es hoy, en el léxico político ordinario, sinónima de opresor. Los que abusaron medio siglo cargaron con la odiosa representación, de la que se libraron los que abusaron durante más de dos siglos, y precisamente los siglos más próximos a nosotros. Es éste un fenómeno que cabe explicar en gran parte por la impresión que produjeron a los hombres del xix $\mathrm{y}$ el $\mathrm{xx}$ las acusaciones vertidas contra los encomenderos en los escritos ideológicos de la época. Hubo una literatura deformadora de la realidad -que exageró los excesos de los encomenderos con fines ideológicos y, con los mismos fines, pasó casi por alto, o palió mucho, los excesos de los corregidores y alcaldes mayores-, y la posteridad sólo ha contado para su información con esa literatura. La información que verdaderamente refleje la realidad vendrá cuando ésta sea estudiada en las copiosas fuentes documentales donde se recoge la vida diaria de la colonia. Y sólo entonces podrá repararse una injusticia relativa, quitando a los encomenderos lo que se les puso de más y añadiendo a los corregidores y alcaldes mayores lo que se les puso de menos.

14 Refiriéndose al efecto que produjo en el hombre europeo el descubrimiento de América, dice Rey Pastor: "Un hálito de optimista entusiasmo inflama las almas antes dormidas; un poderoso aliento vital sublima las existencias más humildes, consagrándolas 
bieran podido realizarse sin engendrar una estela de legítimos intereses, $y$, por otra parte, la indole de la pasión puesta por algunos de los ideólogos en la lid doctrinal denuncia a veces la presencia del ego o la intervención de un marcado interés personal.

Por ende, los intereses de la Iglesia y de la Corona se oponían fundamentalmente a los de los conquistadores-encomenderos, y en ello coincidían. El choque violento de los intereses de aquellas instituciones y los de este grupo a causa de su categórica incompatibilidad dió origen a la más virulenta colisión de fuerzas que registra la historia colonial en su primera época (desde la Conquista hasta las postrimerías del siglo xvI). Son culminantes manifestaciones de ella la polémica Sepúlveda-Las Casas y la segunda guerra civil del Perú; encuentros dialécticos y bélicos en que las ideas y las armas apuntaban a un mismo blanco: el triunfo de unos intereses.

Se oponían también los intereses de la Iglesia y el Estado, por aspirar cada una de estas instituciones a subordinar en ciertos respectos a la otra. La pugna originada por esta oposición no fué verdaderamente muy acusada entre la Corona y la Santa Sede, que marcharon casi siempre de acuerdo en las cuestiones relativas a la conquista y la colonización comunes a ambas, ${ }^{15}$ sino entre las autoridades religiosas y civiles dependientes de los soberanos españoles. Los teólogos peninsulares, que por lo general se opusieron fogosamente a la soberanía temporal del Papa, no impugnaron con igual vehemencia los excesivos poderes eclesiásticos que éste concedió a los reyes de Castilla, convirtiéndolos casi

a ideales de muy diversa alcurnia, pero todos legítimos y aun nobles: el deseo de mejorar la propia vida material, fecundo estímulo del progreso de la humanidad; el ansia de gloria e inmortalidad, que impele hacia las grandes acciones sin medir el sacrificio; el místico afán de convertir a todos los hombres a la verdad que se consideraba absoluta, $y$ el esclarecimiento de las pequeñas verdades de la naturaleza accesibles a nuestra inteligencia." Y cita a continuación unas palabras de Humboldt: "Es un error creer que los conquistadores fueron guiados únicamente por el amor al oro o por el fanatismo religioso. Los peligros elevan siempre la poesía de la vida; y, además, la época vigorosa, cuya influencia en el desarrollo de la idea del mundo buscamos ahora, prestaba a todas las empresas y a las impresiones de la Naturaleza a que dan lugar los viajes lejanos un encanto que empieza a debilitarse en nuestra época erudita, en medio de facilidades sin número que dan acceso a todas las regiones; es decir: el encanto de la novedad y de la sorpresa." Julio Rey Pastor, La ciencia y la técnica en el descubrimiento de América, Buenos Aires, 1942 (Espasa-Calpe, Argentina, Colección Austral), p. 18.

15 Lo contrario pasó con las cuestiones europeas, por las cuales se enfrentaron a menudo en el siglo xvi los Austrias españoles y los Pontífices romanos. 
en soberanos espirituales del Nuevo Mundo. La Iglesia americana -nadie lo ignora- tuvo como cabeza más al monarca español que al Pontífice romano. Debido a las circunstancias señaladas, la pugna se circunscribió al Estado español, dentro de cuyos límites, y acatando siempre la suprema autoridad de la Corona, los magistrados espirituales y los temporales contendieron entre sí para extender su competencia en detrimento de la de los adversarios. Fué una lucha de intereses frenada por el respeto a un interés superior, el nacional, que, tanto en lo religioso como en lo civil, era definido por una sola autoridad suprema: la Corona. Esta aparecía así como poder imparcial, árbitro obligado de las disputas entre las dos jerarquías del reino. Los conflictos eran, por lo tanto, zanjables y extinguibles por una vía regular y pacífica. No por ello dejaron de ser continuos y estridentes. El enfrentamiento de las dos autoridades fué una verdadera constante en la historia colonial, afloración de un pleito secular, no decidido, con su séquito de problemas teóricos y prácticos.

Para concluir, y con vistas a nuestra exposición ulterior, conviene dejar constancia del carácter fundamental de las dos pugnas (IglesiaCorona $v$. encomenderos, y autoridades eclesiásticas $v$. civiles). En torno a ellas giraron los grandes problemas y cuestiones de la conquista de América.

Entre los intereses institucionales en juego, además de los principales o generales, existieron otros secundarios, especiales o particulares, los cuales estuvieron a menudo en pugna con los generales y, permanente o transitoriamente, entre sí. Por ejemplo, los intereses particulares del bajo clero americano, que se opusieron en los orígenes a los generales de la Iglesia, coincidiendo más bien con los de los encomenderos, los del clero regular y el secular, en colisión siempre, y los de las órdenes franciscana y dominica, antagónicos en muchas ocasiones.

Netamente distinguibles de los intereses institucionales y de grupo, por naturaleza colectivos, y en mayor o menor medida generales o públicos, son los intereses particulares, por naturaleza individuales y privados. ${ }^{16}$ Estos intereses, no obstante que su misma condición hubo de relegarlos a rango inferior que los anteriores, revistieron suma importancia en la conquista y colonización de América, que fueron realizadas

10 Son éstos los que estudia el Sr. Zavala, por lo que toca a la conquista de América, en la obra antes citada (nota 9). 
por empresas mixtas, o sea privadas y públicas, en las que desempeñó gran papel el elemento privado, cuyo motor principal era el afán de lucro. Hubo otros motores de la acción interesada de los españoles en América: las aventuras, la gloria militar, el ennoblecimiento, los oficios públicos, etc.; el más común fué sin duda el enriquecimiento, piedra angular del arco económico de la colonia, y también blanco general, por su "sordidez", de los ataques de los idealistas.

Forzoso es reconocer que un interés se impuso a todos los grupos, las instituciones y los particulares: el interés nacional. Por lo que a él respecta, no hubo discrepancia teórica esencial. De una manera u otra, fué principio unánimemente aceptado que América correspondía a España, y ningún autor nacional osó insinuar que fuera abandonada o cedida a otras potencias, ni aun a las católicas, parte de tan dilatado Continente. Los más liberales en otros extremos no pasaron en éste de justificar la exclusión de los demás países católicos, cuando de la evangelización se trataba, con el hecho de haber cometido el Papa al rey de España la predicación del cristianismo allende el Atlántico. Falló, por lo tanto, hasta en los más audaces, la imparcialidad de que hicieron gala cuando era cuestión de otros intereses. El interés nacional fué defendido teóricamente por todos, aun incurriendo en crasas contradicciones. ${ }^{17}$

17 Dos fueron las principa'es: primera, la exclusión de los extranjeros de lo que por derecho de gentes correspondía según Vitoria y otros a todos los hombres, a saber, li libre circulación y el libre comercio en América; segunda, la exclusión de las demás naciones católicas de la obra evangelizadora. Véase infra, Pp. 46-47. 



\section{POSICION GENERAL DE VITORIA FRENTE A LOS INTERESES DE LA CONQUISTA}

La posición general vitoriana frente a dichos intereses está en gran parte determinada y condicionada por dos factores: den $[A]$.

1. Las ideas (doctrinas) y las realidades (intereses) de su or-

2. Los grandes problemas (temas) de su tiempo $[B]$.

$A$ ] La pertenencia a la orden dominica obliga a Vitoria a seguir una corriente teórica, el tomismo (a), y atenerse a los intereses de dicha orden en América, a la realidad que ella quería forjar en el Nuevo Mundo (b).

a) De la corriente teórica, del tomismo, extrae Vitoria la dicotomía básica de su sistema conceptual: la división del mundo en dos órdenes, el natural y el sobrenatural, división de la que se deriva una serie de consecuencias fundamentales en todos los campos, de estructura dicotómica en cada uno de ellos, como en la base. El Derecho, que es uno, se dividirá en dos: el derecho divino y el derecho natural; lo mismo el Poder: poder espiritual y temporal; e igual los fines del hombre: espirituales y temporales; etc., etc. Por su origen y fin, lo divino y lo espiritual se relacionan directamente con Dios, pues de él proceden o a él tienden directamente; mientras que lo natural y lo temporal se relacionan indirectamente con Dios, pues sólo proceden de él o tienden a él indirectamente; de manera inmediata se encaminan a la felicidad terrena de los seres humanos y a satisfacer la condición social del hombre, inherente a su naturaleza.

En lo sencial, he aquí los pilares teológico-filosóficos de la construcción teórica vitoriana. ${ }^{13}$ Nada hay de original en ella. EI principio

18 En el P. Carro, obra antes citada (nota 6), puede hallarse una exposición amplia del sistema teológico vitoriano. 
había sido formulado por Santo Tomás, y las consecuencias, con más o menos precisión, deducidas por él mismo o por sus continuadores, los escolásticos tomistas de los siglos xiv y xv. El mérito de Vitoria está en la claridad y rigor lógico con que desarrolla y aplica esas consecuencias a los problemas de su tiempo, singularmente, a los de la conquista de América.

b) Los desiderata de la orden dominica sobre la realidad americana, sus primordiales intereses en la organización del Nuevo Mundo, están ya netamente delineados cuando Vitoria dicta sus relecciones $D e$ Indis. Vitoria nada les quita ni añade. Los recibe tal como han sido creados en breve e histórica lucha.

El programa de lo que los dominicos quieren que sea la realidad americana puede irse espigando, dentro de un corto período de agitado bregar (unos treinta años), en sermones, peticiones a autoridades, proposiciones y memoriales dirigidos a $S$. M., con trascendencia indudable a textos legales: leyes de Burgos, provisiones de Granada, Leyes Nuevas... Los primeros y capitales puntos de dicho programa se escriben entre el fragor de una de las más enconadas querellas que registra la historia colonial: la disputa de los dominicos de la Española con Ios encomenderos y autoridades de la tierra, secundados éstos por los franciscanos. El célebre sermón de Fr. Antonio Montesino inicia la disputa, y los alegatos ante la Corte del mismo Montesino, de Las Casas y de Fr. Pedro de Córdoba, por el bando dominico, alimentan la polémica una vez generalizada. Sostienen los padres de la Orden de Predicadores como tesis central que los indios son libres y deben ser tratados en consecuencia, tanto en sus personas como en sus bienes, para atraerlos a la fe; ${ }^{12}$ y si por ahora no lo declaran terminantemente, dan a entender que la soberanía de los monarcas españoles no deriva del poder temporal, ya del Papa, ya del Emperador, sino del poder espiritual que tiene la suprema autoridad eclesiástica para la propagación de la fe. ${ }^{20}$ Otro de los puntos de dicho programa, la superioridad del fin espiritual en la Con-

19 Véase "Memorial acerca del gobierno de los indios, presentado en el Consejo de Indias a 11 de dieciembre de $1517^{\circ}$. Colección de documentos inéditos... de Améri$c a$, xII, pp. 106-123.

20 Carta del Rey a Diego Colón (20 marzo 1512): "creyendo [los dominicos de la Española] que no teníamos donación de esa Ista y de las otras tierras y partes de nuestro muy Santo Padre". Cedulario Cubano, pp. 429-31. También, Carta del Provincial de los dominicos a los dominicos que están en las lndias. Ibid., pp. 445-446. 
quista, está ya implícito en los anteriores, pues los indios deben ser "bien tratados como personas libres para los atraer a la fe", ${ }^{21}$ y el rey de España funda su soberanía sobre América en la obligación contraída con la Santa Sede de difundir el cristianismo. Pero este punto está también implícito en el temprano intento de evangelización pacífica realizado por los dominicos en Cumaná: si el fin primordial de la Conquista era la evangelización, sobraban los soldados españoles, que la entorpecían con sus depredaciones y concupiscencias. La superioridad, por razón de su eminencia, del fin espiritual en la Conquista, manifestada en diferentes respectos teóricos y prácticos, quedó inserta como punto capital en el programa dominico desde los primeros tiempos, junto a aquellos otros puntos también capitales.

Como hemos dicho, estas ideas y estas realidades de la orden dominica condicionan y determinan la posición general vitoriana frente a los intereses de la Conquista. No podemos concebir a Vitoria moviéndose en órbita propia. Su pensamiento tuvo que ceñirse a los principios teóricos e ideológicos de la orden a que pertenecía. La discrepancia fundamental con ellos no era admisible. Una posición contraria hubiera abierto un abismo entre Vitoria y su comunidad. La pertenencia a la orden y la permanencia en ella suponían la aceptación en lo fundamental de su teorética y de su ideología.

Naturalmente que no repugnaría a Vitoria esa dependencia, sino, al contrario, le placería, puesto que le brindaba ocasión para sostener principios humanitarios que rimaban de manera cabal con sus convicciones, escuetamente reveladas en algunos escritos privados, ${ }^{22}$ donde arde la pasión que pone en defensa de las ideas propuestas en las relecciones. Por otro lado, sería absurdo pensar que Vitoria hubiese propugnado pareceres contrarios a sus convicciones, ya que nadie le obligaba a ello. Y todavía cabe agregar que sólo la coincidencia del entusiasmo y el fervor dimanados de profundos sentimientos con lo que era doctrina e interés de su orden pudo engendrar un sistema que, además de encerrar cierta originalidad, contribuye considerablemente al breve y limitado retoñar que durante el siglo xvı conoció en España la ya marchita escolástica.

21 Véase Memorial citado en la nota 19.

22 Véase principalmente su carta al Padre Arcos, transcrita en gran parte más adelante, PP. 42-44. 
Pero sin dejar de convenir en todo esto, siempre habrá que admitir lo otro: que Vitoria se mueve dentro de la teorética y la ideología de la orden dominica; y que, a causa de ello, tiene que aparecer apresado por su ya remota tradición teológica (el tomismo) y por su inmediata tradición ideológica americana, y también, por añadidura, sirviendo a los intereses sobre que descansa esta última tradición.

Así condicionado y determinado, Vitoria ha conseguido elaborar con rara habilidad, como nadie lo logró en su tiempo, un sistema teórico de alcance positivo en que se conjugan armoniosamente las ideas recibidas con la ideología resultante de actitudes adoptadas frente a la realidad. En su siglo, ¿quién, como él, ha conseguido enlazar de manera tan diáfana y lógica principios teológicos y políticos con ideas aún no perfiladas sobre una realidad naciente, sumamente confusa y enmarañada; ni asentar la defensa de intereses institucionales sobre cimentación más ética y humana?

B] Como parte de la realidad teórico-práctica de su orbe, heredaba Vitoria de los siglos anteriores dos pugnas fundamentales, que constituían temas ejes de estudios y disertaciones, pues en torno de ellas giraban la exposición y el discurso: la pugna feudalismo-absolutismo y la pugna Iglesia-Estado. Ambas se imponen a los pensadores contemporáneos y actúan, por ello, como condicionantes de su obra.

$\mathrm{La}$ pugna absolutismo-feudalismo es, de las dos, la que en el siglo xvi español, después de la derrota de los comuneros, se muestra más apagada. Pero esa pugna, virtualmente decidida ya en la Península a favor del absolutismo, cobra nuevos bríos y actualidad en América. Por imperativo de las circunstancias, ${ }^{23}$ nacerían en el Nuevo Mundo durante la Conquista poderes autónomos intermediarios, cuasi-feudales, incompatibles con el régimen que comenzaba a imperar en España (el absolutismo) y con las recientes tendencias eclesiásticas (centralistas y autoritarias). La pugna encomenderos-Corona e Iglesia es renovación de la vieja pugna medieval, y aunque al entremezclarse con las cuestiones capitales de la Conquista se presenta en términos algo diferentes, no por eso deja de tener siempre detrás, y de estar manifiesta en ella, la tradicional pugna en que hinca sus raíces. No por muy notoria debe dejar

${ }^{23}$ Estas circunstancias no pueden ser señaladas aquí. Somera y parcialmente me refiero a ellas en un trabajo que aparecerá en breve en el tomo il de los Anales del Instituto de Antropología e Historia ("La función económica del encomendero"). 
de registrarse aquí la enorme trascendencia real de la pugna encomenderos-Corona e Iglesia: fué ésta, sin ningún género de duda, la pugna que con más violencia sacude y más visiblemente agita, en los orígenes, la vida colonial americana.

La pugna Iglesia-Estado llega más viva que la anterior al siglo del P. Vitoria. Las incidencias, alternativas y avatares de la lucha entre ambas potestades llenan la historia medieval. Acapara entonces esa pugna la atención de los pensadores, principalmente de los teólogos y juristas, que, arrebatados por ella, se enzarzan en fogosas polémicas doctrinales, las cuales imprimen a la literatura política de la época un peculiar sello fisionómico; y absorbe asimismo el interés de los gobernantes -eclesiásticos y civiles-, quienes mueven sus fuerzas y recursos sobre el tablero político inducidos o solicitados por esa pugna. Que no parece concluir nunca. Se decide, primero, durante el siglo $\mathrm{xI}$, en un sentido teocrático con el triunfo del papa Gregorio VII sobre el emperador Enrique IV. Se resuelve luego, a fines del siglo xut, en un sentido cesarista con el triunfo de Felipe el Hermoso, rey de Francia, sobre el papa Bonifacio VIII. Finalmente, tanto en la teoría como en la práctica, favorecida por los principiles tomistas, se estabiliza durante los siglos $\mathrm{xv}$ y xvi en la doctrina y arreglo tácito de las dos potestades independientes. Queda circunscrita entonces la pugna al área de la competencia de ambos poderes, pues no estando bien delimitada esa competencia, era inevitable el forcejeo. Los teólogos tomistas hacen hincapié en la separación de las dos potestades, fundándose en la distinción que someramente mostramos antes, ${ }^{24}$ mas comprendiendo que por fuerza habrá ocasiones, principalmente tratándose de materias mixtas, en que el fin espiritual entre en colisión con el fin temporal, consideran como axiomática en estos casos la subordinación de la autoridad civil a la eclesiástica. La subordinación tiene como base la eminencia del fin; se impone, como diríamos con palabras de Vitoria, "sólo en orden al fín espiritual". Si la lucha entre el feudalismo y el absolutismo repercutió en América, renovándose en la contienda entre los encomenderos y la Corona e Iglesia, la lucha entre el poder espiritual y el temporal trascendería también al Nuevo Mundo, renovándose en la lid entre las

24 Supra, p. 19. 
autoridades eclesiásticas y las civiles dentro de la monarquía -como indicamos ya. ${ }^{25}$

En América, el supremo rango que desde un principio se atribuyó al fin religioso benefició a la Iglesia e incitó a algunos a poner rotundamente sobre el tapete la cuestión de la preeminencia de los intereses espirituales y la supremacía del poder eclesiástico. No se trataba de volver a las andadas, reclamando para el Sumo Pontífice una posición largo tiempo perdida, sino de lograr para la Iglesia española una situación de primacía en América; concretamente, de colocar a las autoridades religiosas sobre las civiles en la solución de los problemas fundamentales de la Conquista y en el superior gobierno de los indios.

Esta pugna entre el poder espiritual y el temporal, como la antetior, entre el feudalismo y el absolutismo, tuvo que solicitar fuertemente a Vitoria, quien, lo mismo que los demás teólogos de la época, batalló por hallarle solución teórica.

En suma: Una serie de elementos teóricos y prácticos se impone a Vitoria, encauzando y circunscribiendo su pensamiento:

las ideas y las realidades de su orden y

los grandes problemas de su tiempo.

Los primeros le obligan a seguir una corriente teórica y a ceñirse a una realidad.

Los segundos le constriñen a plantearlos y resolverlos, convirtiéndolos, por tanto, en temas centrales de su discurso. ${ }^{23}$

La posición teórica general de Vitoria frente a los intereses de la Conquista se integra y organiza con los primeros elementos y gira casi siempre en torno de los segundos.

25 Supra, p. 15.

26 Tres de sus principales relecciones, la "De la Potestad Civil" y las dos "De la Potestad de la Iglesia", están dedicadas de lleno a aquellos grandes problemas. 


\section{III \\ VITORIA Y LOS INTERESES INSTITUCIONALES $Y$ DE GRUPO}

1. Vitoria, defensor de los intereses del poder espiritual.

En la relección primera De Potestate Ecclesiae, Vitoria construye teóricamente la doctrina de la supremacía del poder espiritual, la cual aplicará después a todas las cuestiones que se le van ofreciendo en otros tratados y estudios. Naturalmente, la doctrina abogará por que en la vida real se subordinen y cedan los intereses temporales a los espirituales, cuya primacía era entonces postulado dogmático para los católicos. Vitoria en su discurso llega lo más lejos que podía llegar entonces un tomista en la determinación del alcance de esa primacía.

Parte el maestro salmantino, en su argumentación, de la ya indicada división del mundo en dos órdenes. Recoge, para comenzar, una aseveración de Hugo (De Sacra, pars 2): "Hay una vida terrena y otra espiritual. Para que en ambas se guarde la justicia y se encuentre provecho, se determinó primero quiénes hayan de procurar, según la necesidad, los bienes de las dos, y después quiénes hayan de repartirlos, guardando la debida equidad." Sigue a continuación Vitoria, por su cuenta: "Luego si no es posible la duración de la humana sociedad sin las dos vidas, espiritual y terrena, resultan necesarias las dos potestades, para que se conserve la justicia: una que dirija las cosas materiales y gobierne la vida terrena, y otra que rija las espirituales y ordene la vida espiritual." ${ }^{27}$ Se trata de dos potestades separadas e independientes, por razón de sus fines, facultades, etc. "La potestad temporal -asegura Vitoriano depende del Sumo Pontífice, como dependen otras autoridades es-

${ }^{27}$ Relección "De la Potestad de la Iglesia", cuestión primera, cap. v. Ed. latinoespañola de las Relecciones Teológicas, de Luis G. Alonso Getino, Madrid, 1934, t. II, p. 9. Para abreviar, en lo sucesivo citaremos sólo la página o páginas de esta edición y no las cuestiones y capítulos de las relecciones. 
pirituales inferiores, por ejemplo, el episcopado y el sacerdocio." ${ }^{28}$ Por lo tanto, "la potestad civil no está sometida a la potestad temporal del Papa", ${ }^{29}$ ni "la potestad temporal depende absolutamente de la espiritual, como dependen un arte o facultad inferiores de otra superior". ${ }^{30}$ (Según veremos, no existe dependencia absoluta y directa entre la primera y la segunda, sino una supeditación o dependencia relativa e indirecta.) Quedaba, pues, sentada la separación del poder rector de los hombres en dos órdenes conforme a los cánones tomistas. Pero como no era categórica o completa, ${ }^{31}$ tenía Vitoria que buscar solución teórica a los conflictos originados por las inevitables relaciones entre los dos orbes, solución que venía dictada por la preeminencia lógica del fin espiritual, según la enunciara Santo Tomás. "He aquí la diferencia que hay entre la potestad eclesiástica y la civil -asegura Vitoria-. Esta nace de la república, pues sirve para conseguir el fin natural de ella...; en cambio, la eclesiástica aventaja no sólo a toda autoridad particular, sino a la de todo el mundo..." 3

Pero no se trata "de discutir si una de las dos potestades es más perfecta que la otra, pues todos reconocen que la espiritual es más elevada y excelente y de suprema dignidad", sino "de saber si el Papa es superior a todos los príncipes y potestades temporales", ${ }^{33}$ o sea, de saber ya si en la práctica la potestad temporal está subordinada a la espiritual.

Para Vitoria, la contestación viene impuesta por la preeminencia del fin: "Todo lo que tiene un fin debe considerarse con relación a él: así las facultades, las artes, las potencias. Tanto sobrepasa el fin de la potestad espiritual al de la temporal cuanto la perfecta bienaventuranza y la última felicidad excede a la felicidad humana y terrena." ${ }^{34}$ Por ello, "a pesar de lo dicho [sobre la separación de las dos potestades], la potestad civil está sometida de algún modo, no a la temporal del Sumo Pontífice, sino a la espiritual. Porque si el fin de una facultad depende del fin de otra, la primera facultad depende también de la segunda...

28 Ibid., Getino, I, p. 65.

29 lbid., Getino, II, p. 66.

so Ibid., Getino, il, p. 71.

3t Ibid., Getino, n, p. 74: “... la Iglesia es un cuerpo; y no se divide en dos porque haya república civil y espiritual..."

32 Ibid., Getino, II, p. 40.

33 lbid., Getino, II, pp. 60-61.

34 lbid., Getino, 1l, p. 61. 
Pero el fin de la potestad temporal depende de algún modo del de la espiritual; luego aquélla depende de ésta. Se prueba porque la felicidad humana, siendo imperfecta, tiene que ordenarse a la bienaventuranza perfecta, que es la sobrenatural... Si la potestad temporal no estuviese de alguna manera sometida a la espiritual y ordenada a ella, aun concediendo que el bien espiritual sea el mayor, no se seguiría ninguna obligación de conservar el bien espiritual con detrimento del material... Luego si la república civil y la espiritual fuesen independientes, como lo son dos repúblicas temporales o como son dos artes que no se relacionan entre sí, el príncipe no tendría obligación de atender a los asuntos espirituales con daño material de la república... Esto se confirma porque la Iglesia es un cuerpo; y no se divide en dos porque haya república civil y espiritual, sino que sigue siendo uno solo, como consta del testimonio aducido de San Pablo; pues Cristo es cabeza de la Iglesia y tan monstruoso sería un cuerpo sin cabeza como una cabeza con dos cuerpos; y en un cuerpo todo está unido y subordinado, y los miembros menos nobles existen y son por los más nobles. Luego en la república cristiana todo está unido y enlazado: los oficios, los fines y las autoridades, y de ningún modo puede decirse que las cosas espirituales son por las materiales, sino al contrario, que éstas dependen de aquéllas". ${ }^{85}$

Así precisada la índole de la separación de las dos potestades, Vitoria puede acometer ya la tarea de fijar el alcance concreto de la subordinación de la temporal a la espiritual. "En orden al fin espiritual -afirma-, el Papa tiene amplísima potestad temporal sobre todos los príncipes, reyes y emperadores. Lo primero, o sea que la Iglesia tenga poder temporal en orden al fin espiritual, se prueba porque, como ya se ha dicho, las cosas materiales son necesarias y están de alguna manera ordenadas a un fin espiritual. Si Cristo no dejara alguna potestad para emplear y ordenar convenientemente las cosas materiales con relación a un fin espiritual, no hubiera provisto suficientemente el orden espiritual. Ahora bien, los príncipes desconocen la proporción y relación entre lo espiritual y lo temporal, y no tienen tampoco el gobierno de los negocios espirituales: luego este gobierno y empleo de lo material para un fin espiritual le pertenece a la potestad eclesiástica. Luego si para la conservación y gobierno de los asuntos espirituales es necesario emplear

35 Ibid., Getino, u, pp. 72-75. 
medios materiales o la espada o el poder temporal, el Papa podrá hacerlo. $\mathrm{Y}$ digo que tiene potestad amplísima, porque en todo lo que sea necesario y siempre que sea necesario para el fin espiritual, puede el Papa cuanto pueden los príncipes temporales, y, además, quitar y poner príncipes, dividir los reinos y otras cosas parecidas." ${ }^{36}$

Y el decidir en última instancia si una cuestión es temporal, lo atribuye Vitoria al Papa, sellando así la subordinación práctica del poder civil al eclesiástico. "... Habiendo dejado Cristo - sigue discurriendoa la única Iglesia dos potestades distintas para la conservación y aumento de los bienes espirituales y temporales, y pudiendo originarse dudas y dificultades entre ellas, no estaría la Iglesia suficientemente provista si no hubiese alguna autoridad que resolviese en definitiva tales dificultades... Y como no sería razonable atribuir esta autoridad a los príncipes seculares, que no pueden juzgar rectamente de lo espiritual, habrá que atribuirla con mejor derecho a los príncipes de la Iglesia. Por consiguiente, si algo es necesario para la vida espiritual de los súbditos, aunque cause algún detrimento en el gobierno de los bienes materiales, éstos deben posponerse. Por tanto, así como el conocimiento de las cosas espirituales pertenece a los prelados de la Iglesia, así también el juicio y comparación de las cosas espirituales con las temporales debe pertenecerles." ${ }^{3}$

De estos principios se vale Vitoria al dilucidar y resolver ciertas cuestiones concretas. "... Lo mismo en los pactos matrimoniales que en los demás contratos y relaciones civiles -afirmará en la relección De Matrimonio- le pertenece a la potestad espiritual dirigir el poder $\mathrm{y}$ autoridad civil en lo que se relacionen con los asuntos espirituales y señalar los términos y fijar los límites a los que en estas materias pueden llegar." ${ }^{8} 8$

Entre las cuestiones concretas a que aplicará los referidos principios no dejarían de encontrarse las suscitadas por la Conquista. Y así, en virtud de la separación de las dos potestades, el Papa no tendrá autoridad temporal sobre los indios ni sobre los demás infieles; ${ }^{39}$ pero como sí la tiene sobre las cosas temporales en orden a las espirituales, y

36 lbid, Getino, 11, p. 76.

37 Ibid., Getino, II, Pp. 80-81.

38 Relección "De Matrimonio", Getino, II, p. 477.

39 Relección primera "De los Indios", Getino, II, p. 330. 
como "especialmente corresponde al Papa el procurar la promoción del Evangelio en todo el mundo, si para la predicación del Evangelio tienen más facilidades los príncipes de España, puede encomendársela a ellos y prohibirla a todos los otros". ${ }^{40}$

Obsérvese que Vitoria, desarrollando lógicamente sus principios, no cierra el paso totalmente a la derivación del título de los reyes de una concesión del Papa, sino a esa derivación por la vía natural -potestad temporal directa del Sumo Pontífice-. Este encarrilamiento por vía única, que pudiera parecer mero recurso dialéctico, tiene enorme trascendencia teórica y práctica, pues al desplazar fundamentalmente el título de la conquista del terreno de lo natural al de lo divino, colocaba. Vitoria en primer término el fin espiritual, derivando hacia molino propio el caudal de las consecuencias: supremacía del poder eclesiástico, naturaleza espiritual de la empresa americana, rango inferior de los intereses materiales, etc., etc.

En resumen, aclarando y precisando los principios tomistas, Vitoria elabora una doctrina de la supremacía eclesiástica que satisfacía perfectamente a los intereses de la Iglesia española y a los de la orden dominica.

En sus proyecciones americanas, esa doctrina era la que, sin salirse del marco teológico tradicional, "justificaba" y "legitimaba" de manera más diáfana, armoniosa, noble y lógica la conquista y la dominación españolas, suministrando, por ello, a los intèreses que respaldaba una base teórica difícilmente expugnable. Este es "el fuerte" de Vitoria: el sólido enraizamiento en el tomismo y en hondos sentimientos humanos, junto a la perfecta correspondencia con los desiderata generales de la Iglesia española y los particulares de su orden.

El pensamiento vitoriano sobre la Conquista corre a lo largo de líneas netas, que arrancan del principio general de la división del mundo en las esferas natural y divina. A distinta esfera, títulos de conquista distintos y justificación diferente de la guerra. Nos interesa, sobre todo, lo relativo a los títulos, pues la justificación de la guerra guarda estrecha relación con ellos.

En la esfera natural radica Vitoria ciertos derechos (el de viajar y establecerse en países extraños, comerciar con sus habitantes y gozar de lis cosas que en ellos son comunes), de los que se derivan títulos para los. 4n Ibid, Getino, n, p. 369. 
españoles. ${ }^{41}$ Estos derechos sólo justifican la guerra en el caso de oposición a su disfrute. En la misma esfera son situables otros títulos de conquista admitidos por Vitoria, la tiranía de los señores indígenas y las leyes inhumanas, la verdadera y voluntaria elección y la amistad y alianza. ${ }^{42}$

En la esfera divina enclava Vitoria el derecho a la propagación de la fe, cuya negación u obstrucción justifican la guerra y la conquista. ${ }^{43}$

Vemos, pues, que Vitoria no excluye de su sistemática algunos títulos que por la vía natural pueden llegar a justificar la conquista. Excluye, eso sí, los títulos, tanto civiles como eclesiásticos, basados en el derecho positivo o en poderes políticos y sociales. Los títulos que admite por la vía natural son Ios más excelsos que entonces cabía imaginar: los correspondientes a derechos propios del hombre, como individuo, y de toda la comunidad humana; los dimanados del derecho de gentes, cuya virtualidad proviene del derecho natural y no del positivo. Por ende, en la esfera natural, Vitoria coloca teóricamente los títulos de los españoles por encima de sus derechos o intereses particulares, elevándolos a una categoría común a toda la humanidad, donde no podían ser atacados por exclusivistas o injustos o como encubridores de ambición o de codicia. Pero también da la coincidencia de que Vitoria dejaba de este modo desguarnecido de títulos directos al monarca español, es decir, de títulos independientes, como hubieran sido los fundados en sus derechos o poderes positivos.

A los títulos de derecho de gentes o natural se sumaba el de derecho divino: la evangelización. Conocidos ya los pivotes del pensamiento vitoriano, no hay que decir que éste y aquellos títulos no tienen igual rango. Corresponde la preeminencia a la evangelización, ante la cual los demás títulos deben inclinarse. En consecuencia, el título superior de la presencia de los españoles en América era la propagación de la fe. Y todavía se amarran más los cabos para que la subordinación de lo temporal -fin y poder- no tenga escape. Pues si bien dicha evangelización es un derecho de todos los cristinnos, no obstante, el Papa, en virtud de su "potestad sobre las cosas temporales en orden a las espirituales", pudo encomendar la propagación de la fe en América a

41 lbid., Getino, It, pp. 357-363.

42 Ibid, Getino, II, pp. 374-377.

43 lbid., Getino, II, pp. 368-373. 
los monarcas españoles y prohibirla a los demás príncipes cristianos.4 La deducción general obligada es ya clara: el monarca queda investido por la Iglesia del título preeminente -la evangelización-, y debido a ello sujeto al fin espiritual $\mathrm{y}$ a la institución a quien primordialmente correspondía la administración de lo conducente a este fin.

En una palabra, la primacía del fin espiritual y la subordinación de lo civil a lo eclesiástico quedaban establecidas sobre los firmes cimientos de la teología y conforme a los sanos principios del dogma católico y del derecho humano.

Los intereses generales de la Iglesia española y los particulares de la orden dominica contaban ya con un sólido sustentáculo teórico. Puestas una y otra a sacar consecuencias de construcción tan bien asentada y rematada, la acción del poder espiritual en América pudo contar desde entonces con un programa de puntos claros y terminantes:

La Conquista debe ser una conquista espiritual.

Las directrices y orientaciones de la Conquista deben venir de la Iglesia. ${ }^{45}$

Los misioneros deben preceder a los soldados, y éstos recibir órdenes de aquéllos.

Los intereses materiales - de conquistadores, encomenderos, mercaderes, etc.- deben supeditarse, y sacrificarse, a los espirituales.

Las autoridades civiles deben ceder en sus choques, conflictos o diferencias con las autoridades eclesiásticas.

Los indios deben ser educados e instruídos por religiosos y no por civiles, y en lo posible sustraídos a la relación o trato con éstos. Etc., etc., etc.

Vitoria no es sólo el inspirado enunciador de principios generales sobre los que cabe sostener airosamente los intereses del poder espiritual, sino también uno de los pensadores que con más precisión y decisión van sacando las consecuencias prácticas de dichos principios. Pasemos

44 Ibid., Getino, 11, p. 369.

45 "... los juristas no están lo suficientemente peritos para poder definir por sí semejantes cuestiones [las de la Conquista]... Y puesto que se trata de algo que entra en el fuero de la conciencia, al sacerdote, esto es, a la Iglesia, toca fallar." Relección primera "De los Indios", Getino, k1, pp. 291-292. 
revista a algunas de las que deduce en relación con la conquista de América.

Consecuencia sobre quiénes deben aconsejar al monarca en los asuntos de Ultramar: "En segundo lugar, digo que no pertenece a los jurisconsultos fallar este asunto o al menos a ellos solos. Porque como aquellos bárbaros no están sujetos... por derecho humano, sus cosas no pueden ser examinadas por las leyes humanas, sino por las divinas, en las cuales los juristas no están lo suficientemente peritos para poder definir por sí semejantes cuestiones. Ni sé con toda certeza que, para el examen y sentencia de este asunto, hayan sido llamados teólogos dignos que pudieran con garantía ser oídos sobre materia de tanta monta. Y puesto que se trata de algo que entra en el fuero de la conciencia, al sacerdote, esto es, a la Iglesia, toca fallar." 46

Consecuencia sobre la forma en que se hace la evangelización: "No se ve, pues, que les haya sido predicada la religión de Cristo lo bastante piadosa y convenientemente para que estén obligados a asentir. Aunque es verdad que muchos religiosos y eclesiásticos varones, con su vida y ejemplos y diligente predicación, hubieran puesto el trabajo e industria suficientes en este negocio, de no haber sido estorbados por otros, cuyos intereses son muy ajenos a eso." 47 EI fin espiritual es opuesto aquí a los intereses materiales y civiles para mostrar el mal camino que se sigue o los vicios en que se incurre. La consecuencia es que, dado el fin espiritual de la Conquista, debe evitarse la interferencia de los intereses materiales en lo perteneciente a tal fin.

Consecuencia sobre el empleo de la guerra, aun en el caso de ser justa: "Todas estas cosas que se han dicho [acerca de la guerra debida a oposición a la evangelización y a agravios a predicadores y conversos] hay que entenderlas hablando de lo que de suyo dan de sí. Porque puede ocurrir que estas guerras, matanzas y despojos, más bien impidieran la conversión de los bárbaros que la fomentaran y propagaran. $\mathrm{Y}$, por tanto, lo primero que en todo esto debe precaverse es el no poner obstáculo alguno al Evangelio; porque si se pone, entonces hay que abandonar ese modo de evangelizar y buscar otro." 48

Consecuencia sobre el cambio de señores en relación con la con-

46 Ibid., Getino, и, pp. 291-292.

47 lbid., Getino, II, p. 344.

48 Ibid., Getino, II, p. 372. 
servación de la fe: "Si una buena parte de los bárbaros se hubiera convertido a la fe de Cristo, ya sea por las buenas ya por las malas, esto es, por amenazas y temores, o de otro modo injusto, con tal que de hecho sean verdaderamente cristianos, el Papa puede, pídanlo ellos o no, habiendo causa razonable, darles un príncipe cristiano y quitarles los otros señores infieles. Se prueba, porque si así conviniera a la conservación de la religión cristiana, por temerse que apostaten de la fe bajo señores infieles, o con tal ocasión sean oprimidos por sus señores, puede el Papa, en favor de la fe, cambiar los señores." $4: 3$ Adviértase cómo se concede al Papa por la vía espiritual lo que se le niega por la vía temporal; y también cómo se "deseculariza" este título -conveniencia espiritual $\mathrm{y}$ autoridad eclesiástica.

Según afirmamos ya, Vitoria priva al monarca de verdaderos títulos directos de conquista. Ninguno de los que le inviste provendrá de derechos o poderes propios. En especial, el más eminente de todos, el de la propagación de la fe, es el que con más "corporeidad indirecta" le atribuye Vitoria. Es un título que le trasfiere la autoridad en cuyo dominio enraiza. El maestro salmantino tiene especial cuidado en ir desaferrando al poder civil de todo asidero propio. La misma evasión por los escapes indirectos del derecho de gentes le es cerrada en último término con los tupidos y espinosos setos de la supremacía del poder espiritual. Con ellos tapa Vitoria todas las salidas. Donde se encuentran se halla el límitc del área cedida por la suprema autoridad eclesiástica a la civil: “... como aquellos bárbaros no están sujetos por derccho humano, sus cosas no pueden ser examinadas por las leyes humanas, sino por las divinas... Y puesto que se trata de algo que entra en el fuero de la conciencia, al sacerdote, esto es, a la Iglesia, toca fallar." ${ }_{50}$

La supeditación de lo temporal a lo espiritual no podía ser más completa y "razonable". Partiendo de la separación e independencia se había llegado a la subordinación. De manera consumada, Vitoria vertebraba sólidamente el cuerpo doctrinal de la supremacía eclesiástica y sacaba a los intereses institucionales religiosos de la semiorfandad teórica en que todavía se encontraban.

49 Ibid., Getino, r, p. 373.

50 lbid., Getino, II, Pp. 291-292. 
2. El enfrentamiento de Vitoria con los defensores de la independencia del Estado y de lo temporal.

Una doctrina de la supremacía eclesiástica tan magistralmente construída tenía que alarmar a los partidarios de la independencia del Estado y de la subordinación de la Iglesia en lo temporal, singularmente a los letrados de la Corte. Contra ellos, en realidad, dirigía sus armas Vitoria, renovando con nueva táctica la antigua lucha entre teólogos y legistas, y dando estado en el campo teórico a la lid que en América o sobre América veníase sosteniendo, más que en ese campo, en el positivo. Pues Vitoria es quien verdaderamente lanza el reto para la discusión teórica amplia sobre términos precisos y quien deslinda claramente los campos beligerantes, despliega estratégicamente las fuerzas y señala sin titubear los objetivos.

La contienda que pocos años antes se produjera principalmente en la realidad americana y en torno de ella, y trascendiera de manera vaga e imprecisa al terreno especulativo, se traslada ahora plena y definitivamente a la palestra teórica.

Sepúlveda fué el principal contradictor de Vitoria en la justa doctrinal. Sus tesis no tienden a defender, sobre todo, como tan a menudo se afirma, los intereses de los encomenderos, sino los del poder temporal. Percatado, sin duda, de la fuerza arrolladora de la argumentación vitoriana, se esforzará Sepúlveda, más que en rebatirla en sus principios, en reducir el alcance que le da su autor.

No cabía que Sepúlveda negara la preeminencia del fin espiritual, pero sí que, partiendo de la misma división tomista del mundo en dos órdenes, atribuyera a la Conquista un carácter primordialmente temporal y que considerara la evangelización como parte de la obra que un monarca cristiano debía realizar en los pueblos sometidos.

Tuvieron que mostrársele muy claramente las consecuencias de dar a la Conquista un eje espiritual, cual el de la propagación de la fe; consecuencias que ya antes de Vitoria se encontraban manifiestas en las pretensiones de muchos religiosos: abandono de la dirección de la Conquista a los eclesiásticos, subordinación absoluta de los intereses materiales a los espirituales, etc., etc. Para cerrar el paso a estas consecuencias hizo Sepúlveda lo contrario de Vitoria. En lugar de situar principalmente la Conquista en la esfera de lo divino, la enclavó en la esfera de lo natural. 
No tenía mucho que buscar Sepúlveda para hallar autoridad que le suministrara fuerte asidero teórico. Ninguna mejor entonces que Aristóteles, único gran filósofo profano incorporado con todos los honores a la teología católica.

El principio de la desigualdad natural del Estagirita le servirá como fundamento general de su sistema discursivo. A evangelizar -misión sobre todo de la Iglesia- opone civilizar - misión sobre todo del Estado-: “... Será siempre justo y conforme al derecho natural que tales gentes [bárbaras e inhumanas, ajenas a la vida civil y a las costumbres pacíficas] se sometan al imperio de príncipes y naciones más cultas y humanas, para que, merced a sus virtudes y a la prudencia de sus leyes, depongan la barbarie y se reduzcan a vida más humana y al culto de la virtud. Y, si rechazan tal imperio, se les puede imponer por medio de las armas, y tal guerra será justa según el derecho natural lo declara." 51

No quiere esto decir que Sepúlveda prescinda de la evangelización como título justificativo de la Conquista. Pero así como Vitoria procuró dar primacía a la predicación de la fe, así Sepúlveda procura dar primacía, o por lo menos preferencia, por lo que se refiere al sometimiento de los indios, a la superioridad natural de los españoles. $Y$ lo hará no sólo clasificando en primer lugar, entre las justas causas de guerra, la barbarie de los indígenas americanos, sino supeditando el empleo de la fuerza para la evangelización a la inferioridad de los pueblos: "Cuando los paganos no son más que paganos y no se les puede echar en cara otra cosa sino el no ser cristianos, que es lo que llamamos infidelidad, no hay justa causa para castigarlos ni para atacarlos con las armas: de tal modo, que si se encontrase en el Nuevo Mundo alguna gente culta, civilizada y humana..., parece que contra estas gentes sería ilícita la guerra, y en esto tienen razón los teólogos [algunos]... cuando dicen que no basta la infidelidad para que los príncipes cristianos lleven sus armas contra los que viven en ella." ${ }^{52}$ La evangelización de los pueblos bárbaros tendrá, pues, la misma base teórica que su "civilización"; envangelizarlos y civilizarlos funciones son de una misma idea: la de la superioridad de los españoles; y ninguna de las dos puede realizarse sin el sometimiento previo de los indígenas. La necesidad de

51 Sobre las justas causas de la guerra contra los indios, ed. Fondo de Cultura Económica, México, 1941 , p. 85.

62 lbid., pp. 117-119. 
este sometimiento previo viene también determinada por la barbarie de los naturales -la inferioridad de éstos-, pues no cabe pensar en cumplir aquellas funciones sino después de reducidos los bárbaros al imperio español. ${ }^{53}$

Por lo tanto, de la inferioridad de los indios y de su barbarie saca Sepúlveda estas primordiales consecuenciales: Según ley natural, deben ser sometidos los indios por pueblos superiores para ser civilizados y evangelizados; el sojuzgamiento previo por la fuerza es absolutamente indispensable. La evangelización quedaba así englobada en la obra general de regeneración reclamada por la inferioridad de los indios -un título profano emanado de la ley natural-y supeditada a la acción guerrera. El poder civil, por el lado militar, como elemento encargado del sometimiento, y por el lado gubernativo, como elemento encargado de presidir la labor general de civilización, era trasladado de este modo al primer término de la escena.

No podemos extendernos más en el examen del pensamiento de Sepúlveda. Lo expuesto basta para ver hasta qué punto las ideas del humanista tuvieron por objeto impugnar las del teólogo. La renovación de la pugna feudal sobre bases modificadas había impuesto la reelaboración de doctrinas. Vitoria construyó la tesis del bando clerical; Sepúlveda fraguó la tesis del bando laico -que fué una verdadera antítesis de la anterior. A la primacía del título fundado en la ley divina, oponía Sepúlveda la de un título fundado en la ley natural; al derecho principalmente indirecto de la Corona, el derecho directo; a evangelizar, civilizar; a la conquista espiritual, pacífica por lo general, la conquista material, empleando la fuerza; etc., etc.

El papel que Vitoria había jugado en relación con los intereses del poder espiritual, lo juega después Sepúlveda en relación con los intereses del poder temporal. Salvando distancias y diferencias, puede afirmarse que los dos construían doctrinas coherentes y completas en abono de los intereses que les importaban. En su terreno, indudablemente las doctrinas más coherentes y completas de la época. Por eso los dos autores personifican las dos posiciones en pugna. La relación de ambos con los intereses que apoyan parece evidente. Sin embargo, aunque se asegura bastante a menudo que Sepúlveda defendió los intereses de los encomenderos - lo cual es bastante inexacto, pues Sepúlveda 53 Ibid., p. 93. 
defendió principalmente los intereses del poder temporal, como ya hemos dicho-, en cambio, no se afirma nunca que $V$ itoria sostuvo los intereses del poder espiritual. Obedece esto a la ya vieja costumbre de poner a quienes reverenciamos entre los ángeles buenos y a quienes despreciamos entre los ángeles malos. Aquella imputación se dirigiría a incluir a Sepúlveda en esta última grcy; mientras que el pasar por alto la relación de Vitoria con los intereses tendría quizá por objeto no mezclarle en los asuntos que se estiman impuros para que pueda figurar dignamente en la categoría de los ángcles buenos.

3. Vitoria, defensor, en particular, de los intereses de la Iglesia española.

Al defender los intereses de la Iglesia, Vitoria no tiene presentes principalmente los intereses de toda la comunidad católica, que representaba la Santa Sede, sino en particular los de la Iglesia española. Ya hemos dicho que el Sumo Pontífice marchó ordinariamente de acuerdo con el soberano español sobre los asuntos de América. Las bulas relativas al Nuevo Mundo sellaron desde el principio esa inteligencia entre las dos potestades, cristalizada en fórmulas que se acomodaban perfectamente a las realidades de la Conquista y a lo todavía vivo de la tradición medieval.

Pues bien, una parte de la Iglesia española, la secular, aceptó como de buena ley los términos o bases del arreglo, que fueron, como se sabe, el traspaso a la Corona española de los territorios descubiertos en Ultramał y la concesión del patronato universal de la Iglesia americana a los reyes de Castilla, con la obligación, para éstos, de predicar la fe y sufragar los gastos de culto y clero. Pero otra parte de la Iglesia española, la regular, si bien no puso reparo fundamental al acomodo, no se consideró satisfecha con el principio en que éste parecía fundarse: la soberanía temporal del Papa. Tal principio tenía que contrariar a quienes preconizaban la eminencia del fin espiritual y derivaban de ella la supremacía del poder eclesiástico.

Los dominicos llevaron la voz cantante en la impugnación del principio que echaba por tierra sus tesis. Y lo hicieron aun a sabiendas de que incurrirían en el enojo papal. Lo cual, por otra parte, no amilanaba gran cosa a aquellos religiosos, prontos siempre a anteponer los intereses particulares de la Iglesia española a los universales de la romana. Que la política del Vaticano y la misma persona del P’apa sólo debían ser 
respetadas cuando no se opusieran a los supremos intereses de España, entendida ésta como comunidad mixta -religiosa y civil-, fué idea que pareció imperar entre los religiosos hispanos, y singularmente entre los dominicos. Recuérdese, si no, la frase de Melchor Cano: "Al Papa, primero atarle las manos, y después besarle los pies." Vitoria no anduvo muy remiso en manifestar el respeto relativo que le merecía la cabeza suprema de la Iglesia: "Yo por agora -escribe en carta al Condestable de Castilla, D. Pedro Fernández de Velasco, en 19 de noviembre de 1536- no pediría a Dios otra merced sino que hiciese a estos dos príncipes [Carlos V y Francisco I] hermanos en la voluntad como lo son en el deudo, que si esto hubiese no habría más herejes en la Iglesia ni aun más moros de los que ellos quisiesen, y la Iglesia se reformaría, quisiera el Papa o no; y hasta que esto no vea $\mathrm{ni} d a r e ́$ un maravedí por el Concilio, ni por cuantos remedios ni ingenios se imaginaren. La culpa no debe estar en el rey de Francia, ni mucho menos en el Emperador..." ${ }_{54}$

Por consiguiente, los dominicos, presididos en lo teórico por Vitoria, se enfrentaron con el Papa, y también con el Emperador, en lo relativo el punto concreto de la procedencia del poder que el primero traspasaba al segundo. No podía molestar mucho a los dos supremos jerarcas el que se les negase por una vía - la temporal- lo que se les acordaba por otra -la espiritual-; pero, de todas maneras, no pudieron pasar sin censura o reproche lo que constituía un reto a su autoridad. Apenas nos han llegado testimonios de "réplica" papal. Uno bastante elocuente es la determinación tomada por Sixto $V$ de incluir en el Indice las relecciones de Vitoria "porque, a su juicio, limitaban excesivamente el poder pontificio". ${ }^{55}$ Y esto ocurría muy a fines del siglo, cuando la resonancia de las doctrinas vitorianas se había apagado mucho. El Emperador sentó más fuertemente su poderosa mano sobre quienes se permitían discutir la validez de un título a la conquista de América que él antepuso siempre a cualesquiera otros. El testimonio más importante de la "réplica" cesárea es una carta dirigida por Carlos $\mathrm{V}$ al prior del convento de San Esteban de Salamanca el 10 de noviembre de 1539 , cuyo texto es el siguiente: "Venerable prior del mo-

54 Getino, El maestro Francisco de Vitoria, p. 219.

55 Getino, Relecciones internacionalistas del P. Mtro. Fray Francisco de Vitoria, Madrid, 1934, Introducción, p. 20. 
nasterio de santisteban de la cibdat de salamanca yo he sydo ynformado que algunos maestros religiosos de esa casa han puesto en platica y tratado en sus sermones y en repeticiones del derecho que nos tenemos a las Indias yslas e tierra firme del mar oceano y también de la fuerza $\mathrm{y}$ valor de las composiciones que con la autoridad de nuestro santo padre se han fecho y facen en estos reynos y porque de tratar de semejantes cosas sin nuestra sabiduria y sin primero nos avisar dello mas de ser muy perjudicial y escandaloso podria traer grandes ynconvenientes en deservicio de Dios y desacato de la sede apostolica e bicario de Cristo e daño de nuestra Corona Real destos reynos, abemos acordado de vos encargar y por la presente vos encargamos y mandamos que luego sin dilacion alguna llameis ante vos a los dichos maestros y religiosos que de lo susodicho o de cualquier otra cosa de ello ovieren tratado asi en sermones como en repeticiones o en otra cualquier manera publica o secretamente y recibais dellos juramento para que declaren en que tiempos y lugares $y$ ante que personas han tratado $y$ afirmado lo susodicho asi en limpio como en minutas y memoriales, y si dello han dado copias a otras personas eclesiasticas o seglares; y lo que ansy declararen con las escripturas que dello tovieren sin quedar en su poder ni de otra persona copia alguna, lo entregad por memoria firmada de vuestro nombre a fray niculás de santo tomas que para ello enviamos para que lo traiga ante nos y lo mandamos ver y proveer cerca dello lo que convenga al servicio de Dios y nuestro y mandarles eys de nuestra parte y vuestra que agora ni en tiempo alguno sin expresa licencia nuestra no traten ni prediquen ni disputen de los suso dicho ni hagan ymprimir escriptura alguna tocante a ello porque de lo contrario me terne por muy deservido y lo mandare proveer como la calidad del negocio lo requiere." ${ }^{56}$

Parece inexplicable esta actitud real si no se relaciona con los intereses que suscitó la Conquista. Pues équé cabe aducir para justificar la reacción del monarca en el caso de los dominicos y en el de Sepúlve$\mathrm{da}^{57}$ que fueron distintos, y aun contrarios (si el rey reprueba una tesis, por qué condena a quien la impugna), y para justificar la no rep. 7.

56 Getino, Relecciones intermacionalistas del P. Mtro. Fray Francisco de Vitoria,

57 A Sepúlveda se le negó licencia para publicar su Democrates 11 ; también se mandó recoger su Apología, impresa en Roma en 1550. 
acción en el caso del Obispo de Chiapas que abundaba en las mismas ideas de Vitoria?

En la lucha contra los encomenderos, el soberano español tuvo como aliados a Ios religiosos, principalmente a los dominicos, y por eso quizá no puso coto a una propaganda como la de Las Casas, quien en el terreno doctrinal, por carecer de autoridad, tenía que parecerle inofensivo. No ocurría lo mismo con los teólogos dominicos de Salamanca, entre los que se hallaba Vitoria -cuya fama como pensador y como maestro había cundido por todos los ámbitos de España y trasponía sus fronteras. ¿No había de contrariar al Emperador que personas tenidas casi por oráculos en conventos y universidades, centros del saber de entonces, impugnaran un título que abonaba una larga práctica de la cristiandad? Es seguro que sí. También hay que contar con que los alarmados juristas de la Corte no desperdiciaran la ocasión y echaran abundante leña al fuego.

El aliado se había salido de las líneas generales del plan de campaña, debilitando el frente, y sufría la reprimenda del general en jefe. Los dominicos, al buscar base firme a la superioridad del poder espiritual, aunque sin proponerse menoscabar fundamentalmente los derechos del soberano -conforme vimos-, rebasan los límites de la conveniencia real y tienen que aguantar el real palmetazo. Algo parecido le ocurre a Sepúlveda: al buscar resistente asidero a la superioridad del poder temporal, traspasa asimismo las lindes de la conveniencia real, favoreciendo a los encomenderos, y también incurre en el enojo de Su Majestad. Dentro de lo que al rey interesaba, tanto los dominicos como Sepúlveda se extralimitaban; y su extralimitación resultaba enojosa al monarca porque, así los primeros como el segundo, gozaban de gran predicamento, aquéllos entre los teólogos, éste entre los letrados. Lo cierto es que ni Sepúlveda ni los dominicos se proponían impugnar los derechos del soberano; antes al revés, tiraban a defenderlos; pero como se esforzaban además en sostener la primacía de un poder -el espiritual o el temporal-, la necesidad de armonizar lo uno con lo otro les hizo discrepar en parte con las ideas y principios más del imperial agrado. $\mathrm{Y}$ aquí es donde aparece con mayor claridad el entrelazamiento de las pugnas de intereses. No se podían defender los del poder espiritual a la manera -muy lógica- de Vitoria sin que se resintieran algo los del monarca -pues éste resultaba desvestido de títulos propios al recibir 
del Papa, con un fin no secular, los derechos de conquista-; ni se podían defender los intereses del poder temporal a la manera -también muy lógica- de Sepúlveda sin que los del rey fueran afectados de algún modo - pues en la naturaleza humana, base de la defensa de aquéllos, no cabía encontrar otro apoyo que la diferente condición de los seres humanos, lo cual era alegado como justificación de la encomienda-- De haber seguido las doctrinas de Vitoria, el monarca se hubiera visto sometido a una excesiva tutela eclesiástica; de haber aceptado las ideas de Sepúlveda, hubiera tenido que transigir más o menos con las encomiendas. Y el rey no quería ni lo uno ni lo otro; su deseo era desembarazarse de los encomenderos y mantener un prudente equilibrio entre las autoridades eclesiásticas y las civiles. Deseo que a la larga fué el que prevaleció.

\section{Vitoria y los intereses de los enconnenderos}

Poco hay que añadir aquí a lo expuesto antes.

Viroria no dirige sus tiros especialmente contra los encomenderos, sino contra todos los que obstaculizaban la cumplida realización del fin espiritual. Entre ellos se hallaban naturalmente los gobernantes civiles de América y, sobre todo, los que disfrutaban de repartimientos de indios, a quienes correspondía en sus distritos la educación religiosa de los naturales. Por lo tanto, dependiendo en gran medida de los encomenderos la evangelización de los indios, sin mencionarlos, contra ellos se revolvía principalmente Vitoria en su relecciones De Indis. Pues más que nadie eran ellos los que se interponían entre la Iglesia y los indígenas, impidiendo que se realizara debidamente el fin espiritual de la Conquista. De dos cosas ante todo cabía acusarlos: de incumplir o desatender sus deberes religiosos hacia los indios y de imponerles exacciones abusivas y vejarlos en sus personas. Lo primero obstaculizaba directamente la propagación de la fe; lo segundo, indirectamente. Y parecía obligado que los encomenderos incurrieran corrientemente en ambas irregularidades, puesto que de ello deducían indudables provechos materiales: menos gastos, por un lado, y más ingresos, por otro. Este fué el punto flaco de los encomenderos en la lucha que sostuvieron con la Iglesia y la Corona. En la naturaleza de sus intereses se hallaban implícitos el incumplimiento de sus obligaciones y la explotación de los indios. A los ataques fundados en esto podían replicar los 
encomenderos presentándose teóricamente como los más celosos protectores de sus vasallos indígenas. Pero como en la práctica el interés material de los encomenderos ostentó sin recato su verdadera faz, la base teórica de la alegada tutela paternal tuvo que desmoronarse.

Vitoria fué uno de los principales demoledores de esa base teórica, al dejar doctrinalmente bien sentada la primacía del fin espiritual y sublimar como nadie el carácter evangelizador de la Conquista. Su piqueta fué quizá la que con mayor eficacia contribuyó a derribar los bastiones levantados en defensa de la sojuzgación por la fuerza, es decir, de la conquista bélica y la evangelización coactiva, que fueron en gran parte los progenitores de la encomienda.

“... por la guerra los bárbaros no pueden ser movidos a creer, sino a fingir que creen y que abrazan la fe cristiana", nos dirá en la primera relección De indis, parte II, cap. 15 , párrafo 7.58

Si los indígenas americanos han de ser traídos al cristiano redil pacífica y persuasivamente, no parecían muy indicados para esta labor los soldados convertidos en encomenderos. Estos, dados sus intereses, constituían verdadero estorbo o rémora de la evangelización: “. . . no están obligados a creer [los bárbaros] -advierte en dicha relección- si la fe no se les propone con motivos probables de persuasión. Pero milagros y señales no veo ninguno, ni tan religiosos ejemplos de vida. No se ve, pues, que les haya sido predicada la religión de Cristo lo bastante piadosa y convenientemente para que estén obligados a asentir. Aunque es verdad que muchos religiosos y eclesiásticos varones, con su vida y ejemplos y diligente predicación, hubieran puesto el trabajo e industria suficientes en este negocio, de no haber sido estorbados por otros, cuyos intereses son muy ajenos a eso". 59

Empezaban los encomenderos, como soldados, por desbaratar el terreno -esterilizar el campo donde había de sembrarse la nueva fe-con sus atropellos y felonías. Nada le saca más de quicio a Vitoria que las atrocidades y desafueros cometidos durante la Conquista. Particularmente, los perpretados en el Perú le ofenden y enfurecen. En la carta que dirige al Padre Arcos hacia 1534 vibra la indignación que provocó

58 Relecciones teológicas, ed. Getino, II, p. 346.

59 lbid., Getino, II, p. 344. 
en él la conducta de los "peruleros". "Destos del Perú -escribe--, timeo que no sean de aquellos qui volunt divites fieri. Y por algunos se dijo: Impossibile este divitem intrare in regnum caelorum. Aquí, pues esta hacienda fué ajena, no se puede pretender otro título a ella, sino jure belli. Primum omnium, yo no entiendo la justicia de aquella guerra; nec disputo si el emperador puede conquistar las Indias, que praesuppono que lo puede hacer strictisimamente. Pero a lo que yo he entendido de los mismos que estuvieron en la próxima batalla con Tabalipa, nunca Tabalipa ni los suyos habían hecho ningún agravio a los cristianos ni cosa por donde los debiesen hacer la guerra. Sed responden los defensores de los peruleros, que los soldados no eran obligados a examinar eso, sino seguir y hacer lo que mandaban los capitanes. Accipio responsum para los que no sabían que no había ninguna causa más de guerra, más de para roballos, que eran todos o los más. Y creo que más ruines han sido las otras conquistas después acá. Pero no quiero parar aquí. Yo doi todas las batallas y conquistas por buenas y santas. Pero hase de considerar que esta guerra, ex confessione de los peruleros, es, no contra extraños, sino contra verdaderos vasallos del emperador, como si fuesen naturales de Sevilla, et praeterea ignorantes revera justitiam belli; sino que verdaderamente piensan que los españoles los tiranizan y les hacen guerra injustamente. $\mathrm{Y}$ aunque el emperador tenga justos títulos de conquistarlos, los indios no lo saben ni lo pueden saber; $\mathrm{y}$ así virissime sunt innocentes quantum attinet ad bellum. $\mathrm{Y}$ así, supposita tota justitia belli ex parte bispanorum, non potest bellum ultra procedere más de hasta subjetarlos y compelerlos a que resciban por su príncipe al emperador, in quantum fieri poterit, minimo damno et detrimento illorum, y no para robarlos y echarlos a perder quantum spectat ad bona temporalia. Que la guerra, máxime con los vasallos, hase de tomar y proseguir por el bien de los vasallos y no del príncipe, $s i$ quid habet veri vatum praesagia, id est, los dichos de los santos y doctores. Ni sé por dónde puedan robar y despojar a los tristes de los vencidos de cuanto tienen y no tienen. En verdad, si los indios no son hombres, sino monas, non sunt capaces injuriae. Pero si son hombres y prójimos, et quod ipsi prae se ferunt, vasallos del emperador, non video quomodo excusar a estos conquistadores de última impiedad y tiranía, ni sé que tan grand servicio hagan a su magestad de echarle a perder sus 
vasallos. Si yo desease mucho el arzobispado de Toledo, que está vaco, $\mathrm{y}$ me lo hoviesen de dar porque yo firmase o afirmase la inocencia destos peruleros, sin duda no lo osara hacer. Antes se seque la lengua y la mano que yo diga ni escriba cosa tan inhumana y fuera de toda cristiandad..."

60 P. Viccntc Beltrán de Heredia, "Ideas del maestro Fray Francisco de Vitoria anteriores a las relecciones De Indis accrca de la colonización de América, según documentos inédito", Amuario de la Asociación Francisco de Vitoria, vol. It, PP. 32-34. 


\section{IV \\ VITORIA Y EL INTERES NACIONAL}

El interés nacional, que consistía en reservar el monopolio de América al Estado español, fué sostenido y justificado por Vitoria de igual manera que lo hicieran, en general, los que consideraron como justo título básico de conquista la propagación de la fe: "Aunque esto sea común y pertenezca a todos [la predicación de la religión cristiana] pudo, sin embargo, el Papa, encargar este asunto a los españoles y prohibírselo a los demás", sienta en la primera relección De Indis. ${ }^{61}$

Esta causa de exclusión fué la más alegada desde que se rechazó por lo común como improcedente la soberanía temporal del Papa sobre los infieles. Aunque el Papa no podia ceder lo que no le correspondía -derechos de soberanía-, sí le era dado regular lo que era de su incumbencia -la evangelización-, atribuyendo a un monarca cristiano esta función de manera exclusiva. Vitoria aduce la causa $-y$ se vale de la argumentación - de la mayoría; pero como una y otra no casan bien con los principios sobre los cuales va urdiendo la trama de su discurso, se ve obligado a introducir en éste nuevos razonamientos, dirigidos, más que nada, a rebatir de antemano las objeciones previstas.

En efecto, razona Vitoria: "Y no sólo puede prohibir a estos últimos [los demás monarcas católicos] la predicación, sino también el comercio, si fuera esto conveniente para la propagación de la religión cristiana, puesto que puede ordenar las cosas temporales como convenga a las espirituales. Luego, si esto fuera conveniente, caería dentro de la autoridad y poder del Sumo Pontífice. Pero parece que es en absoluto conveniente; porque si de otras naciones cristianas concurriesen indistintamente a aquellas provincias, es fácil que mutuamente se estorbaran y surgiesen muchas disensiones, por donde se impediría la tranquilidad y

${ }^{61}$ Relecciones Teológicas, Getino, In, p. 369. 
se turbaría el asunto de la fe y conversión de los bárbaros. Además, puesto que los príncipes españoles fueron los primeros que, bajo sus auspicios y con su dinero, tomaron sobre sí aquella navegación y descubrieron tan felizmente el Nuevo Mundo, justo es que tal peregrinación o viaje se prohiba a los demás y ellos solos gocen de lo descubierto." ${ }^{6 \mathrm{x}}$

Con esta argumentación pretende cerrar Vitoria las brechas que abría en su propio sistema al admitir el principio de exclusión. Pues si por derecho de gentes era lícito recorrer las provincias americanas y permanecer en ellas, así como participar en las cosas comunes, principios que son tenidos por los más originales y revolucionarios del pensamiento vitoriano, ¿no era improcedente negar, líneas después, a los extranjeros el goce de esos derechos, derivados del de gentes, es decir, negar a otros pueblos derechos propios de todas las naciones y de todos los hombres, aduciendo pretendidas ventajas para la propagación de la fe y dando como bueno un precepto regulatorio del Romano Pontífice?

$\mathrm{El}$ interés nacional ciega a Vitoria, obligándole a salir por un momento de su irreprochable vía lógica. Por no comprometerlo, se ve forzado a ser incongruente y a caer en palmaria contradicción. Lo cual salta a la vista cuando en el texto citado antes supedita lo que por derecho de gentes corresponde a todos los hombres a las conveniencias de la predicación de la fe y cuando llega al extremo absurdo de colocar sobre derechos "que la razón natural estableció entre todas las gentes" 63 los intereses creados por la prioridad en los descubrimientos y por las inversiones materiales del Estado español.

Lo congruente y lógico con el pensamiento fundamental vitoriano hubiera sido reconocer el derecho de los extranjeros a recorrer libremente América y a comerciar con los naturales, y también el derecho de los soberanos católicos a propagar la fe en las partes del Nuevo Continente no ocupadas por los españoles. Lo primero era lo que mejor se cohonestaba con lo que a todos los hombres pertenecía por derecho natural y lo segundo lo que mejor se conformaba con los dogmas de la Iglesia y, sobre todo, con las necesidades de la predicación.

¿Está justificado el apego de Vitoria al interés nacional? Para contestar a esta pregunta conviene tener en cuenta lo siguiente: la fuerza

62 lbid., Getino, II, Pp. 369-370.

63 Ibid., Getino, II, P. 358. 
del interés nacional en su tiempo y el hallarse el de los españoles cimentado en muchos años de ingente obra colectiva. En presencia de tales elementos de juicio, ¿no resulta explicable el apartamiento de la consecuencia lógica que se nota en Vitoria?, pues ¿no había de parecerle recusable e ingrato oponer a la entonces grávida y majestuosa realidad del interés nacional las rigurosas deducciones de unos principios abstractos? 



\section{INDICE}

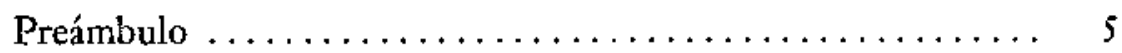

1) Necesidad de estudios imparciales y críticos de la obra de Vitoria $\ldots . \ldots \ldots \ldots \ldots \ldots \ldots \ldots \ldots, 5$

2) Especial necesidad de estudios sobre la relación de las ideas de Vitoria con los intereses de la conquista de América ...............................

I. Las ideas y los intereses de la Conquista $\ldots \ldots \ldots \ldots \ldots \ldots, 11$

II. Posición general de Vitoria frente a los intereses de la Con-

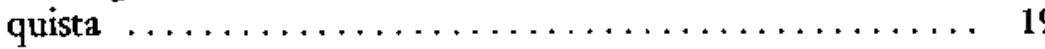

III. Vitoria y los intereses institucionales y de grupo $\ldots \ldots \ldots \ldots 25$

1. Vitoria, defensor de los intereses del poder espiritual.. 25

2. El enfrentamiento de Vitoria con los defensores de la independencia del Estado y de lo temporal ......... 34

3. Vitoria, defensor, en particular, de los intereses de la Iglesia española $\ldots \ldots \ldots \ldots \ldots \ldots \ldots \ldots \ldots \ldots, 37$

4. Vitoria y los intereses de los encomenderos ........ 41

IV. Vitoria y el interés nacional $\ldots \ldots \ldots \ldots \ldots \ldots \ldots \ldots, 45$ 



\section{LISTA DE JORNADAS PUBLICADAS}

1. José Medina Echavarría. Prólogo al estudio de la gzuera (agotado).

2. Tomás Sánchez Hernández. Los principios de la guerra (agotado).

3. Jorge A. Vivó. La Geopolitica (agotado).

4. Gilberto Loyo. La presión demográfica (agotado).

5. Antonio Caso. Las causas bumanas de la guerra.

Jorge Zalamea. El bombre, náufrago del siglo $x \boldsymbol{x}$.

6. Vicente Herrero. Los efectos sociales de la guerra (agotado).

7. Josué Sáenz. Los efectos económicos de la guerra.

8. Manuel F. Chavarría. La disponibilidad de materias primas.

9. Manuel M. Pedroso. La prevención de la guerra.

10. D. Cosío Villegas, E. Martínez Adame, Víctor L. Urquidi, G. Robles, M. Sánchez Sarto, A. Carrillo Flores, José E. Iturriaga. La postguerra. Alfonso Reyes, D. Cosío Villegas, J. Medina Echavarría, E. Martínez Adame, Víctor L. Urquidi. La nueva constelación internacional.

11. Raúl Prebisch. El patrón oro y la vulnerabilidad económica de nuestros paises.

12. José Gaos. El pensamiento bispanoamericano.

13. Renato de Mendonça. El Brasil en la América Latina.

14. Agustín Yáñez. El contenido social de la literatura iberoamericana.

15. José E. Iturriaga. El tirano en la América Latina.

16. Javier Márquez. Posibilidad de bloques económicos en América Latina.

17. Gonzalo Robles. La industrialización en Iberoamérica.

18. Vicente Herrero. La organización constitucional en Iberoamérica.

19. M. F. Chavarría, A. Pareja Díez-Canseco, M. Picón Salas, J. A. Portuondo, L. Alberto Sánchez, J. Vasconcelos, Jorge A. Vivó, J. Xirau. Integración Política de América Latina.

A. Castro Leal. La política internacional de América Latina.

20. Francisco Ayala. Ensayo sobre la libertad.

21. J. A. Portuondo. El contenido social de la literatura cubana.

22. Antonio García. Régimen cooperativo y economía latino-americana.

23. Jesús Prados Arrarte. El plan inglés para evitar el desempleo.

24. Florián Znaniecki. Las sociedades de cultura nacional y sus relaciones.

25. Renato Treves y Francisco Ayala. Una doble experiencia política: España e Italia. 
26. John Condliffe. La política económica exterior de Estados Unidos.

27. A. Cameiro Leão. Pensamiento y acción.

28. Antonio Carrillo Flores. El nacionalismo de los paises latino-americanos en la postguenra.

29. Moisés Poblete Troncoso. El movimiento de asociación profesional obrero en Cbile.

30. José Maria Ots Capdequí. El siglo xviii español en América.

31. Medardo Vitier. La lección de Varona.

32. Howard Becker y Philip Fröhlich. Toynbee y la sociologia sistemótica.

33. Emilio Willems. El problema rural brasileño desde el punto de vista antropológico.

34. Emilio Roig de Leuchsenring. 13 conclusiones fundamentales sobre la guerra libertadora cubona de 1895 .

35. Eugenio Imaz. Asedio a Diltbey. (Un ensayo de interpretación.)

36. Siivio Zavala. Contribución a la bistoria de las instituciones coloniales en Guatemala.

37. Roherto MacLean y Estenós. Racismo.

38. Alfonso Reyes. Tres puntos de exegética literaria.

39. Agustín Yánicz. Fichas mexicanas.

40. José Miranda. El método de la ciencia política.

41. Roger Caillois. Ensayo sobre el espíritu de las sectas.

42. Otto Kirchheimer. En busca de la sobermina.

43. Manucl Calvillo. Francisco Suárez.

44. Juan Bernaldo de Quirós. El seguro social en lberoamérica.

45. Nexander H. Pekelis. Una jnorisprudencia del bien comin.

46. Julio Le Riverend. Los origenes de la economia cubana.

47. Kingsicy Davis. Reflexiones sobre las instituciones políticas.

48. Cuestiones industriales de México.

49. Josué de Castro. Fisiología de los tabús.

50. Max Aub. Discurso de la novela española contemporánea.

51. Lesley Byrd Simpson. Dos ensayos sobre la función y la formación del bistoriador.

52. ILeopoldo Zea. En torno a una filosofía americana.

53. José Ferrater Mora. Cuestiones españolas.

54. Luis A. Santullano. Mirada al Caribe. (Fricción de culturas en Puerto Rico.)

55. Marco Antonio Durán y Julián Rodríguez Adame. Cuestiones agrarias de México.

56. Patrick Romanell. La polémica entre Croce y Gentile. (Un diálogo filosófico.)

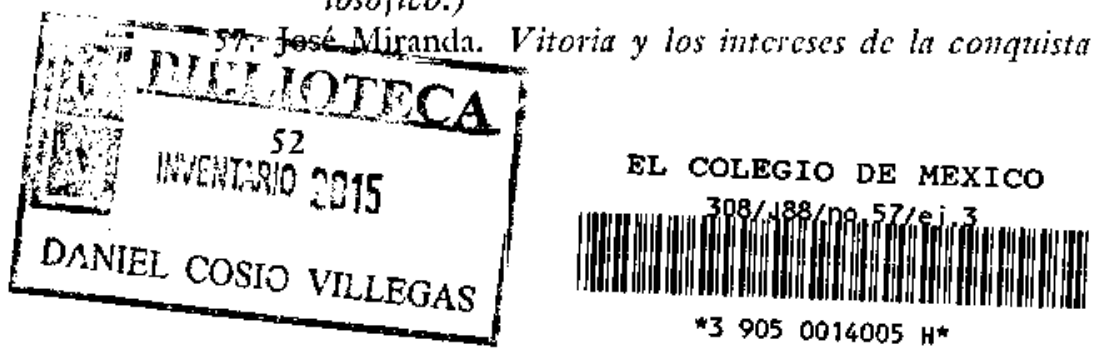


El Colegio de México y el Hispanic Institute (Universidad de Columbia) publicarán trimestralmente la

\section{NUEVA REVISTA DE FILOLOGIA HISPANICA}

Director: Amado Alonso (Harvard University)

Redactores: William Berrien, Américo Castro, Antonio Castro Leal, Fidelino de Figueiredo, Hayward Keniston, Irving A. Leonard, María Rosa Lida, José Luis Martínez, Agustín Millares Carlo, José F. Montesinos, Marcos A. Morínigo, S. G. Morley, Tomás Navarro, Federico de Onís, Alfonso Reyes, Ricardo Rojas, José Rojas Garcidueñas, Angel Rosenblat, Manuel Toussaint y Silvio Zavala.

Redactor bibliográfico: Sidonia C. Rosenbaum (Columbia University)

Secretario: Raimundo Lida (El Colegio de México)

\section{PRECIO DE SUSCRIPCION Y VENTA}

En México: 15 pesos moneda nacional al año; en el extranjero: 5 dólares norteamericanos. Número suelto: 4 pesos moneda nacional y 1.50 dólares, respectivamente.

Redacción y Administración:

EL COLEGIO DE MEXICO

Sevilla, 30 - México, D. F. 
